\title{
Frequency of dementia among elderly admitted to a Geriatrics Inpatients Sector of a Brazilian public hospital
}

\author{
Rafael Thomazi ${ }^{1}$, Liciana Vaz de Arruda Silveira², \\ Paulo José Fortes Villas Boas ${ }^{3}$, Alessandro Ferrari Jacinto ${ }^{3}$
}

\begin{abstract}
Patients with dementia are commonly admitted to inpatient sectors. The aim of this study was to describe the frequency of dementia among elderly inpatients admitted to the Geriatrics Sector of a Brazilian Tertiary University Hospital, and to identify associations between dementia and clinical and sociodemographic factors. Methods: All patients admitted to the Geriatrics Sector of a public Brazilian university-hospital from March $1^{\text {st }} 2014$ to January $31^{\text {st }} 2015$ were assessed by geriatricians. The patients were divided into groups "with or without diagnosis of dementia". Univariate analysis was performed between these two groups using the Chi-Square Test, Student's $t$-test or the Mann-Whitney Test. Results: One hundred and three elderly inpatients, with a mean age of $82( \pm 7.9)$ years, were assessed. Overall, $74.7 \%$ had low educational level (<4 years), 66\% used polypharmacy, 57.2\% developed delirium during hospitalization and $59 \%$ were totally dependent for basic activities of daily living. The diagnosis of dementia was observed in 59 (57\%) subjects. Conclusion: The frequency of dementia was high among the elderly inpatients evaluated. The association between dementia and certain clinical conditions, such as incontinence, delirium and use of psychoactive drugs, was in line with the medical literature.
\end{abstract}

Key words: aged, inpatient, dementia.

FREQUÊNCIA DE DEMÊNCIA EM IDOSOS INTERNADOS EM ENFERMARIA DE GERIATRIA DE UM HOSPITAL PÚBLICO BRASILEIRO RESUMO. Pacientes com demência são comumente admitidos em setores de internação. 0 objetivo deste estudo foi descrever a frequência de demência em pacientes idosos internados em uma enfermaria de geriatria de um hospital universitário terciário brasileiro e identificar associações entre demência e fatores clínicos e sociodemográficos. Métodos: Todos os pacientes internados na enfermaria de geriatria de um hospital universitário público brasileiro no período de 1 de março de 2014 a 31 de janeiro de 2015 foram avaliados por geriatras. Os pacientes foram divididos em dois grupos: com ou sem diagnóstico prévio de demência. Análise univariada foi utilizada na comparação dos resultados dos dois grupos por meio do Teste do Qui-Quadrado, teste t-Student e o teste de Mann-Whitnney. Resultados: Foram avaliados 103 pacientes idosos, com idade média de $82( \pm 7,9)$ anos; 74,7\% apresentaram escolaridade baixa (<4 anos), 66\% usavam polifarmácia, 57,2\% desenvolveram delirium durante a hospitalização e 59\% eram totalmente dependentes das atividades básicas da vida diária. 0 diagnóstico de demência foi observado em 59 indivíduos (57\%). Conclusão: A frequência de demência foi alta entre pacientes idosos avaliados. A associação entre demência e certas condições clínicas, como a incontinência, o delírio e o uso de drogas psicoativas, está em consonância com a literatura médica. Palavras-chave: idoso, hospitalização, demência.

$\mathrm{T}$ he world's elderly population continues to grow at an unprecedented rate. Currently, 8.5 percent of people worldwide (617 million) are aged 65 and over, a figure set to rise to $17 \%$ by $2050 .{ }^{1}$ Population ageing, along with improvements in health care and socioeco-

\footnotetext{
This study was conducted at Internal Medicine Department, Botucatu Medical School, SP, Brazil.
}

${ }^{1} M D$. Internal Medicine Department, Botucatu Medical School - São Paulo State University (UNESP), SP, Brazil; ${ }^{2}$ PhD. Associate Professor, Instituto de Biociências Botucatu, São Paulo State University (UNESP), SP, Brazil; ${ }^{3} \mathrm{MD}$, PhD. Associate Professor, Internal Medicine Department, Botucatu Medical School - São Paulo State University (UNESP), SP, Brazil.

Alessandro Ferrari Jacinto. Disciplina de Geriatria / Departamento de Clínica Médica / Faculdade de Medicina de Botucatu / UNESP - Av. Rubião Jr, s/n 18618-294 Botucatu SP - Brazil. E-mail: alessandrojacinto@uol.com.br

Disclosure: The authors report no conflicts of interest.

Received August 26, 2017. Accepted in final form October 31, 2018.

(cc) BY 
nomic conditions, is paradoxically contributing to the increased prevalence of dementia. ${ }^{2}$ Worldwide, dementia rates range from $5 \%$ to $7 \% .{ }^{3}$ In Latin America, the rate is approximately $7 \%,{ }^{4}$ while in Brazil, ranges from $5.1 \%$ to as high as $19.0 \% .{ }^{5,6}$

Worldwide, 47 million are people living with dementia and this number is projected to increase to more than 131 million by 2050 . The total estimated worldwide cost of dementia is US\$ 818 billion. ${ }^{7}$

Dementia appears to be common in older patients admitted to acute hospitals and is associated with a range of adverse outcomes during hospitalization, including delirium, longer hospital stays, falls and increased mortality. ${ }^{8-14}$

The aim of this study was to describe the frequency of dementia among elderly inpatients admitted to the Geriatrics Sector of a Brazilian tertiary university hospital, and to identify associations between dementia and clinical and sociodemographic factors.

\section{METHODS}

A cross-sectional study assessing all patients admitted to the Geriatrics Sector of the "Hospital das Clínicas de Botucatu" (HCB) between March $1^{\text {st }} 2014$ and January $31^{\text {st }} 2015$ was conducted. The data collected was used to create a database containing sociodemographic, pharmacological and clinical aspects of the inpatients. The diagnosis of dementia was established prior to hospitalization by other doctors and corroborated by geriatricians. The criteria for the diagnosis of dementia published by Frota et al. were used. ${ }^{15}$ Polypharmacy was defined as the continuous use of four or more drugs. Functional status was determined by the Katz Index. For the evaluation of delirium, the Confusion Assessment Method (CAM) was used. ${ }^{16}$

There were no exclusion criteria.

The Geriatrics Sector has eight beds run by a medical team comprising two residents of the Residency Program in Geriatrics of the "Faculdade de Medicina de Botucatu - UNESP" supervised by three Associate Professors of Geriatrics. The HCB is one of the largest public institutions in the State of São Paulo and part of the Brazilian Unified Health System. It is located in the city of Botucatu. The hospital serves 68 cities in an area with a population of two million.

The project was submitted for approval to the Local Research Ethics Committee (65573417.6.0000.5411).

\section{Statistical analysis}

A descriptive analysis of the whole sample was performed. The sample was divided into two groups: "dementia" and "non-dementia". Chi-Square Test and Student t-test were used for comparisons between the two groups. The level of statistical significance adopted was 0.05 .

\section{RESULTS}

One hundred and three elderly inpatients, with a mean age of $82( \pm 7.9)$ years, were assessed. A descriptive analysis of sociodemographic, functional capacity, pharmacological and clinical factors is given in Tables 1 and 2. Regarding sociodemographics and functional capacity, $58.2 \%$ of the patients were male, $78 \%$ had low educational level, $21 \%$ lived in long-term care institutions, and 59\% were totally dependent for basic activities of daily living on the Katz scale. ${ }^{17}$ In terms of pharmacological medical aspects, $66 \%$ were in use of polypharmacy, 33\% antidepressants, $26 \%$ neuroleptics, $24 \%$ benzodiazepines and $20 \%$ acetylcholinesterase inhibitors. For clinical aspects, $64 \%$ had hypertension, $57,2 \%$ dementia, $57.3 \%$ delirium, $42 \%$ depression and $46 \%$ urinary incontinence.

Palliative care support, including end-of-life care, was provided to $16 \%$ of inpatients, with a total of $34 \%$ deaths among all patients admitted to the geriatrics ward during the study period.

There was a significant statistically difference between the "dementia" and "non-dementia" groups in body mass index (BMI) and serum albumin level (SAL). Both BMI and SAL were higher in the "non-dementia" group, as shown in Table 3.

Comparison of "dementia" versus "non-dementia" groups revealed that patients with dementia used more psychotropic drugs, had more urinary incontinence, were more dependent for basic activities of daily living and developed more delirium during hospitalization. All other variables showing a statistically significant difference between the two groups are depicted in Table 4 .

\section{DISCUSSION}

The frequency of dementia at the Geriatrics Sector of the HCB was $57.2 \%$, a higher rate than that reported in other studies conducted mostly in Internal Medicine Inpatients Sectors. The frequency of dementia in elderly inpatients ${ }^{8}$ has been reported as between 20 and $30 \%$. A higher frequency of dementia was expected in a Geriatric Inpatient Sector than in Internal Medicine Inpatient Sectors. One of the studies showing a higher frequency of dementia (63\%) was conducted at a Geriatrics Inpatient Sector in an older, mainly female population. ${ }^{18}$ In the present study, the frequency of dementia was also higher than the rate of approximately $7 \%$ found 
among community-dwellers, ${ }^{3}$ suggesting more frequent hospitalization among the elderly with dementia. Patients with dementia had poorer functional ability than patients without dementia, a finding also reported recently elsewhere. ${ }^{19}$ This group was more likely to have delirium at admission and to develop delirium during admission than patients without dementia. Our findings confirm previous reports regarding the importance of dementia as a risk factor for delirium during hospitalization..$^{20}$ This population also exhibits high rates of incontinence, use of psychotropic drugs, longer hospital stays and higher rates of new institutionalization..$^{21}$ To summarize, it is not dementia itself that leads an elderly patient to be admitted to hospital, but the biologically fragile state that results from dementia and the associated comorbidities. ${ }^{22}$

Table 1. Sociodemographic, functional capacity and pharmacological aspects of the sample.

\begin{tabular}{|c|c|c|c|}
\hline & & $\mathbf{N}$ & $\%$ \\
\hline \multirow[t]{2}{*}{ Gender } & Male & 60 & 58.2 \\
\hline & Female & 43 & 41.7 \\
\hline \multirow[t]{4}{*}{ Marital status } & Married & 30 & 29 \\
\hline & Single & 5 & 5 \\
\hline & Divorced & 8 & 8 \\
\hline & Widowed & 60 & 58 \\
\hline \multirow[t]{2}{*}{ Race } & Black and other & 17 & 16.4 \\
\hline & White & 86 & 83.6 \\
\hline \multirow[t]{2}{*}{ Dwelling } & Botucatu & 89 & 86 \\
\hline & Other & 24 & 14 \\
\hline \multirow[t]{2}{*}{ Education (years) } & $>4$ & 26 & 25.2 \\
\hline & $\leq 4$ & 77 & 74.7 \\
\hline \multirow{2}{*}{$\begin{array}{l}\text { Polypharmacy (Four or } \\
\text { more medications used) }\end{array}$} & Yes & 68 & 66 \\
\hline & No & 35 & 34 \\
\hline \multirow[t]{4}{*}{ Psychotropic use } & Antidepressants & 35 & 34 \\
\hline & Neuroleptics & 27 & 26 \\
\hline & Benzodiazepines & 25 & 24 \\
\hline & Anticholinesterases & 21 & 20 \\
\hline \multirow{3}{*}{$\begin{array}{l}\text { Dependency for } \\
\text { activities of daily living }\end{array}$} & Independence & 13 & 13 \\
\hline & Partial dependence & 29 & 28 \\
\hline & Total dependence & 61 & 59 \\
\hline \multirow[t]{2}{*}{ Feeding } & Tube feeding & 23 & 33 \\
\hline & Oral feeding & 80 & 77 \\
\hline
\end{tabular}

In a prospective study involving a cohort of very old acutely ill geriatric inpatients, higher levels of comorbidity and poor functional status were more predictive than dementia for adverse hospitalization outcomes. ${ }^{23}$ This highlights the importance of carrying out a more in-depth evaluation of hospitalized elderly patients that encompasses social support, comorbidities, functional dependence as opposed to simply identifying a patient in a dementia setting.

As demonstrated in other studies, dementia was also significantly associated with low body mass index (BMI) and poorer nutritional status prior to admission. ${ }^{24}$

Limitations of present study are the convenience sample from a single service and the difference in type of hospitalized elderly patient, since the sample of patients was drawn from a specialized geriatric nurs-

Table 2. Clinical aspects of the sample.

\begin{tabular}{|c|c|c|}
\hline & $\mathbf{N}$ & $\%$ \\
\hline Hypertension & 66 & 64 \\
\hline Dementia & 59 & 57.2 \\
\hline Delirium & 59 & 57.2 \\
\hline Pneumonia & 44 & 42.7 \\
\hline ICU & 16 & 15.5 \\
\hline Depression & 37 & 35 \\
\hline Diabetes & 34 & 33 \\
\hline Dyslipidemia & 31 & 30 \\
\hline Falls in the last year & 31 & 30 \\
\hline Urinary incontinence & 44 & 42 \\
\hline Stroke & 29 & 28 \\
\hline Heart Failure & 30 & 29 \\
\hline Pressure lesion (admission) & 44 & 42.7 \\
\hline Pressure injury (acquired) & 35 & 34 \\
\hline CKD & 17 & 16 \\
\hline Osteoarthrosis & 48 & 46 \\
\hline Osteoporosis & 26 & 25 \\
\hline Previous fractures & 26 & 25 \\
\hline COPD & 10 & 9 \\
\hline Deaths & 35 & 34 \\
\hline
\end{tabular}

UTI: urinary tract infection; CKD: chronic kidney disease; COPD: chronic obstructive pulmonary disease. 
Table 3. Comparison of "dementia" and "non-dementia" groups for body mass index and serum albumin level.

\begin{tabular}{cccc} 
& Dementia Mean ( \pm SD) & Non-dementia Mean $( \pm$ SD) & p \\
\hline BMI & $18.7(16.8 ; 21.4)$ & $22.3( \pm 4.9)$ & $0.01^{*}$ \\
\hline SAL & $2.45(2.1 ; 3.0)^{\#}$ & $2.9( \pm 0.6)$ & $0.01^{\star \star}$ \\
\hline
\end{tabular}

${ }^{*}$ Student's $t$-test; ${ }^{*}$ Mann-Whitney Test; "Median (Interquartile Range); SD: standard deviation; IQR: interquartile range; BMI: body mass index; SAL: serum albumin level.

Table 4. Variables with statistically significant association between "dementia" and "non-dementia" groups.

\begin{tabular}{|c|c|c|c|c|c|c|}
\hline & & \multicolumn{2}{|c|}{ Dementia } & \multicolumn{2}{|c|}{ Non-dementia } & \multirow[b]{2}{*}{$\mathbf{P}^{*}$} \\
\hline & & (N) & $\%$ & (N) & $\%$ & \\
\hline \multirow[t]{2}{*}{ Psychoactive drug } & Yes & 45 & 76.2 & 19 & 43.1 & 0.001 \\
\hline & No & 14 & 23.7 & 25 & 56.8 & \\
\hline \multirow[t]{2}{*}{ Neuroleptic } & Yes & 24 & 40.6 & 3 & 7.1 & $<0.001$ \\
\hline & No & 35 & 59.3 & 39 & 92.8 & \\
\hline \multirow[t]{2}{*}{ HF } & Yes & 11 & 18.6 & 19 & 43.1 & 0.007 \\
\hline & No & 48 & 81.3 & 25 & 56.8 & \\
\hline \multirow[t]{2}{*}{ COPD } & Yes & 2 & 3.3 & 8 & 18.1 & 0.01 \\
\hline & No & 57 & 96.6 & 36 & 81.8 & \\
\hline \multirow[t]{2}{*}{ Incontinence } & Yes & 40 & 67.7 & 4 & 9 & $<0.001$ \\
\hline & No & 19 & 32.2 & 40 & 90.9 & \\
\hline \multirow[t]{2}{*}{ DBADL } & Yes & 48 & 81.3 & 13 & 29.5 & $<0.001$ \\
\hline & No & 11 & 18.6 & 31 & 70.4 & \\
\hline \multirow[t]{2}{*}{ Delirium } & Yes & 41 & 69.4 & 18 & 40.9 & 0.004 \\
\hline & No & 18 & 30.5 & 26 & 59 & \\
\hline \multirow[t]{2}{*}{ Pressure Lesion (admission) } & Yes & 33 & 55.9 & 11 & 25 & 0.002 \\
\hline & No & 26 & 44 & 33 & 75 & \\
\hline \multirow[t]{2}{*}{ Pressure lesion (acquired) } & Yes & 27 & 45.7 & 8 & 18.1 & 0.003 \\
\hline & No & 32 & 54.2 & 36 & 81.8 & \\
\hline \multirow[t]{2}{*}{ Caregiver } & Yes & 24 & 40.6 & 8 & 18.1 & 0.01 \\
\hline & No & 35 & 59.3 & 36 & 81.8 & \\
\hline \multirow[t]{2}{*}{ LTCI } & Yes & 17 & 28.8 & 5 & 11.3 & 0.03 \\
\hline & No & 42 & 71.1 & 39 & 88.6 & \\
\hline \multirow[t]{2}{*}{ Bedridden } & Yes & 45 & 76.2 & 14 & 31.8 & $<0.001$ \\
\hline & No & 14 & 23.7 & 30 & 68.1 & \\
\hline
\end{tabular}

*Chi-Square test; HF: heart failure; COPD: chronic obstructive pulmonary disease; DBADL: dependency for basic activities of daily living; LTCI: long-term care institution. 
ing ward. Elderly patients admitted in this setting usually have more comorbidities, greater frailty, use more medications, including psychotropic combinations, tend to have greater functional decline and longer hospital stays, increasing the risk of developing delirium and infections during hospitalization. Another limitation was the study design. Prospective studies can produce more valid results for investigations of demographic and clinical conditions associated with hospitalization of patients with dementia.

The main contribution of the study is the identification, in a developing Latin American country, of medical conditions associated with the hospitalization of elderly with dementia, possibly fostering the development of preventive and early management care to reduce the chances of subsequent hospital admission. From a strictly institutional standpoint, the early identification and treatment of these conditions can reduce the average length of stay, risk of delirium, exposure to the hospital environment (e.g. risk of infections $)^{25}$ and ultimately, the cost of hospitalization.
Another potential impact of our study pertains to the process of diagnosing dementia within the hospital environment. We note the need for better diagnostic instruments and improved awareness of certain medical conditions associated with dementia, which could lead to earlier diagnosis and its associated positive effects: early relief of symptoms, more effective management of medications and comorbid conditions that could otherwise worsen the patient's cognitive state, improved caregiver education about accident risks, and more timely financial planning for the patient and family. ${ }^{26}$

Author contribution. Rafael Thomazi: collected data, analyzed the results and wrote the manuscript. Liciana Vaz de Arruda Silveira: analyzed data and revised the manuscript writing. Paulo José Fortes Villas Boas: supervised data collection and revised the manuscript writing. Alessandro Ferrari Jacinto: designed the study, supervised data collection, analyzed the results and wrote the manuscript.

\section{REFERENCES}

1. He W, Goodkind D, Kowal P. U.S. Census Bureau, International Population Reports, P95/16-1, An Aging World: 2015, U.S. Government Publishing Office, Washington, DC, 2016.

2. Suh $\mathrm{G}-\mathrm{H}$, Shah A. A review of the epidemiological transition in dementia - cross-national comparisons of the indices related to Alzheimer's disease and vascular dementia. Acta Psychiatr Scand. 2001;104:4-11.

3. World Health Organization. Dementia: A Public Health Priority. Geneva: World Health Organization, 2012.

4. Nitrini R, Bottino CMC, Albala C, Capuñay NSC, Ketzoian C, Rodriguez JJL, Maestre GE, et al. Prevalence of dementia in Latin America: a collaborative study of population-based cohorts. Int Psychogeriatr. 2009;21:622-30.

5. Fagundes SD, Silva MT, Thees MFRS, Pereira MG. Prevalence of dementia among elderly Brazilians: a systematic review. Med J. 2011;129:46-50.

6. Lopes MA, Ferrioli E, Nakano EY, Litvoc J, Bottino CMC. High prevalence of dementia in a community-based survey of older people from Brazil: association with intellectual activity rather than education. J Alzheimer Dis. 2012;32:307-36.

7. Prince M, Comas AH, Knapp M, Guerchet M, Karagiannidou M. World Alzheimer report 2016: improving healthcare for people living with dementia: coverage, quality and costs now and in the future. Alzheimers Disease International (ADI), London, UK.

8. Mukadam N, Sampson EL. A systematic review of the prevalence, associations and outcomes of dementia in older general hospital inpatients. Int Psychogeriatr. 2010;18:1-12.

9. Draper B, Karmel R, Gibson D, Peut A, Anderson P. The Hospital Dementia Services Project: Age differences in hospital stays for older people with and without dementia. Int Psychogeriatr. 2011;23:1649-58.

10. Sampson EL, Blanchard MR, Jones L, Tookman A, King M. Dementia in the acute hospital: Prospective cohort study of prevalence and mortality. Brit J Psychiatry.2009;195:61-6.

11. Zuliani G, Galvani M, Sioulis F, Bonetti F, Prandini S, Boari B, Guerzoni F, Gallerani M. Discharge diagnosis and comorbidity profile in hospitalized older patients with dementia. Int J Geriatr Psychiatry. 2012;27:313-20.

12. Guijarro R, San Román CM, Gómez-Huelgas R, Villalobos A, Martín M, Guil M, Martínez-González MA, Toledo JB. Impact of dementia on hospitalization. Neuroepidemiology. 2010;35:101-8.

13. King B, Jones C, Brand C. Relationship between dementia and length of stay of general medical patients admitted to acute care. Australasian J Ageing. 2006;25:20-23.

14. Fong TG, Jones RN, Marcantonio ER, et al. Adverse outcomes after hospitalization and delirium in persons with Alzheimer disease. Ann Int Med. 2012;156:848-56.

15. Frota NAF, Nitrini R, Damasceno BP, Forlenza O, Tosta ED, Silva AB, Junior EH, Magaldi RM. Critérios para o diagnóstico de doença de Alzheimer. Dement Neuropsychol 2011;5(Suppl 1):5-10.

16. Inouye SK, van Dyck $\mathrm{CH}$, Alessi CA, et al. Clarifying confusion: the confusion assessment method. A new method for detection of delirium. Ann Intern Med 1990;113(12):941-8.

17. Katz S, Akpom CA. Index of ADL. Med Care. 1976;14(5 Suppl):116-8.

18. Torian L, Davidson E, Fulop G, Sell L, Fillit H. The effect of dementia on acute care in a geriatric medical unit. Int Psychogeriatr. 1992;4:231-9.

19. Goldberg SE, Whittamore KH, Harwood RH, Bradshaw LE, Gladman $J R$, Jones RG. The prevalence of mental health problems among older adults admitted as an emergency to a general hospital. Age Ageing. 2011;41:80-6.

20. Elie M, Cole MG, Primeau FJ, Bellavance F. Delirium risk factors in elderly hospitalized patients. J Gen Int Med. 1998;13:204-12.

21. Anderson D, Aveyard B, Baldwin B, et al. (2005). Who cares wins: improving the outcome for older people admitted to the general hospital: guidelines for the development of liaison mental health services for older people. London: Royal College of Psychiatrists.

22. Maia E, Steglich MS, Lima AP, Troncoso $I H Z$, Silva KI, Martins TRC, Neto YC, Lopes MA. Dementia in elderly inpatients admitted to medical wards in Brazil: diagnosis and comorbidity with other clinical diseases. Psychogeriatrics. 2016;16:177-84.

23. Zekry D, Herrmann FR, Grandjean R, Vitale AM, De Pinho MF, Michel JP, et al. Does dementia predict adverse hospitalization outcomes? A prospective study in aged patients. Int J Geriatr Psychiatry. 2009;24: 283-91.

24. Zekry D, Herrmann FR, Grandjean R, Meynet MP, Michel JP Gold $\mathrm{G}$, Krause KH. Demented versus non-demented very old inpatients: the same comorbidities but poorer functional and nutritional status. Age Ageing. 2008;37:83-9.

25. Bôas PJFV, Ruizb T. Ocorrência de infecção hospitalar em idosos internados em hospital universitário. Rev Saude Publica. 2004;38:372-8.

26. Alzheimer's Association. (2012). Alzheimer's disease facts and figures. Alzheimers Dement. 2012;8:131-68. 